\title{
Distribution of alkaline phosphatase in the serum proteins in hypophosphatasia
}

\author{
N. H. KORNER \\ From the Department of Medicine, St. Vincent's Hospital, Sydney, Australia
}

SYNOPSIS A patient with hypophosphatasia and her relatives, including an affected brother, weres studied with regard to serum alkaline phosphatase levels, phosphoethanolamine excretion, leucocyt $\dot{G}$ alkaline phosphatase, blood group genes, and alkaline phosphatase distribution in the serum proteiniw fractions.

The pattern of alkaline phosphatase distribution in the serum protein fractions was normal both in the clinically affected patients and in their relatives. Thus the electrophoretic mobility of serum? alkaline phosphatases is not altered in hypophosphatasia.

The mere presence of phosphoethanolamine in the urine was of no help in detecting heterozygotes for the hypophosphatasia gene(s), as this substance was also found in control urines.

Hypophosphatasia is one of the group of inherited conditions in which a metabolic defect is the consequence of an enzyme deficiency. In this disease low tissue alkaline phosphatase activity is reflected in a low serum alkaline phosphatase level, and the outstanding clinical feature is defective mineralization of bone with resultant skeletal deformities, e.g., genu valgus, Harrison's sulci. The histological and radiological picture of the affected bone resembles that of rickets.

Other clinical features of hypophosphatasia are the premature loss of primary teeth, occasionally craniostenosis, and thoracic skeletal deformities which in severe cases may lead to death from respiratory infection (Engfeldt and Zetterström, 1954). Interstitial renal fibrosis and nephrocalcinosis have been described in badly affected infants but the disease has also been discovered in apparently normal adults after a fracture (Beisel, Austen, Rosen, and Herndon, 1960).

Apart from low levels of alkaline phosphatase activity in the serum, bone, liver (Sobel, Clark, Fox, Robinow, 1953), kidney, small intestine (Harris and Robson, 1959), and leucocytes (Beisel, Benjamin, and Austen, 1959), the main biochemical abnormality is the excretion of excess phosphoethanolamine in the urine (Fraser, 1957). The serum calcium is usually normal, but in severe cases hypercalcaemia has been observed and held responsible for nephrocalcinosis (Fraser, 1957) though renal

Received for publication 2 October 1961. function has not been affected. Serum inorganic phose phorus is usually normal but high levels can occus (Engfeldt and Zetterström, 1954). The probable presence of adenosine monophosphate in the uring has been described but not confirmed (McCance? Fairweather, Barrett, and Morrison, 1956).

The mode of inheritance is believed to be by an autosomal recessive gene (Fraser, 1957; Harris and Robson, 1959).

The purpose of the present investigation was tom study the distribution of alkaline phosphataseactivity in the electrophoretically separated serum protein fractions in two patients with hypophos: phatasia and their relatives. In normal subjects peak alkaline phosphatase activity is in the alpha 20 globulins, and beta globulins have somewhat more than half the alpha 2 activity. Albumin activity often more than $10 \%$ of the total (Korner, 1962) but alpha 1 and gamma activity is less than thiso (Rosenberg, 1959; Keiding, 1959). Any marked changes in the electrophoretic mobility of serum alkaline phosphatases in hypophosphatasia migh thus be expected to cause deviation from the normaf pattern of enzyme distribution.

The phosphoethanolamine excretion, leucocyte alkaline phosphatase, and blood groups of the affected family are also described below, togethes with the case history.

\section{CASE REPORT}

The patient, a girl aged 26 months, was admitted to Str Vincent's Hospital, Sydney, in June 1959. She was th8 


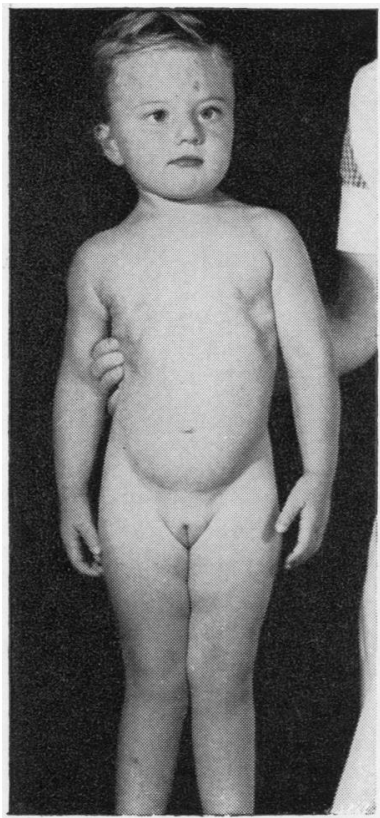

FIG. 1A

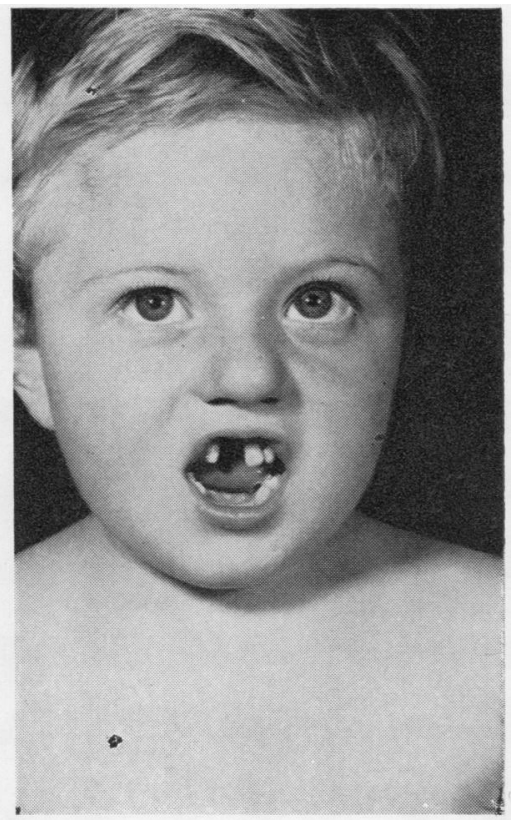

FIG. 1B

FIG. 1. A, the propositus, showing genu valgus, Harrison's sulci, and a squint; $B$, the propositus, showing loss of incisor teeth; $C$, bones of the legs, showing metaphyseal defects in femora, tibiae, and fibulae. The tibiae are bowed.

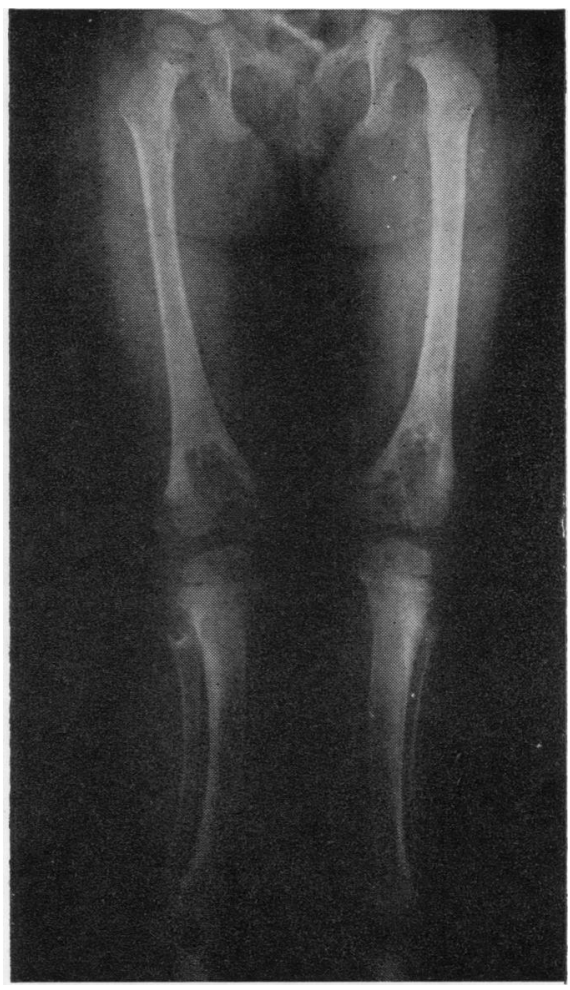

FIG. $1 \mathrm{C}$ fourth child in the family, and pregnancy and delivery had been normal.

Her head was thought to be somewhat abnormal in shape since birth. The forehead was high, and a small lump was present near the posterior fontanelle, which was later followed by the appearance of a hard lump at the site of the anterior fontanelle, and a ridge running backwards along the sagittal suture. The mother thought that a small anterior fontanelle was present at birth.

The patient was breast fed for 10 days and was then put on an adequate artificial feeding régime. She gained weight and made satisfactory progress; at the age of 1 year she started to stand, but she did not walk till 19 months. Medical advice was sought because she could not walk as well as expected, and tended to overbalance. She was 'knock-knee'd' and 'walked on the insides of her feet'.

Her teeth appeared at the normal times, but she began to lose some at the age of 13 months, and in all lost five teeth. Her ribs were noted to be unusual in shape, and a slight squint appeared when she was almost 2 years old. Prominent blue veins on her forehead had been present since the age of 12 months.

She started to speak at the age of 2 years, and development as regards eating, toilet training, intelligence, and emotional responses seemed quite normal. She had suffered no fractures, or other relevant illnesses.
PHYSICAL EXAMINATION She was a child of normal size (height $82.5 \mathrm{~cm}$., weight $12 \cdot 7 \mathrm{~kg}$.), with a high, prominent skull vault, and a ridge of bone running from the site of the anterior fontanelle back along the sagittal suture, giving the appearance of craniostenosis. The veins over the forehead were prominent, and there was a minor degree of convergent strabismus. The head circumference was $46.5 \mathrm{~cm}$. Her gait was somewhat awkward, but the optic fundi and the remainder of the central nervous system were normal.

Genu valgus deformity, Harrison's sulci, and a rachitic rosary were present (Fig. 1). One upper and four lower incisor teeth were missing. No other abnormality was detected clinically.

PROGRESS Details of biochemical and radiological investigations are given in Table $I$.

It was decided to treat the craniostenosis surgically, and a left parietal cranioplasty was performed. An incision in the left parietal bone extending for threequarters of the circumference of an ellipse was lined with polyethylene film. The child recovered well, and six months later was re-admitted for operation on the right parietal bone. She had made good progress (height $87 \mathrm{~cm}$., weight $12.3 \mathrm{~kg}$.) but her movements and gait remained somewhat clumsy. The rachitic rosary was no longer evident, but physical examination was otherwise unchanged. 
TABLE I

INVESTIGATIONS OF PROPOSITUS

Serum alkaline phosphatase (King-Armstrong units $/ 100 \mathrm{ml}$.)
Serum calcium (mg./100 ml.)
Serum phosphorus (mg./100 ml.)
Urine phosphoethanolamine
Blood urea (mg. $/ 100 \mathrm{ml}$.
Serum electrolytes $(\mathrm{mEq} . / 1$.
Serum proteins $(\mathrm{g} . / 100 \mathrm{ml}$.
Electropherogram
Radiographs
Other enzymes
Haematological
W.R., Eagle, Kline tests
Urine

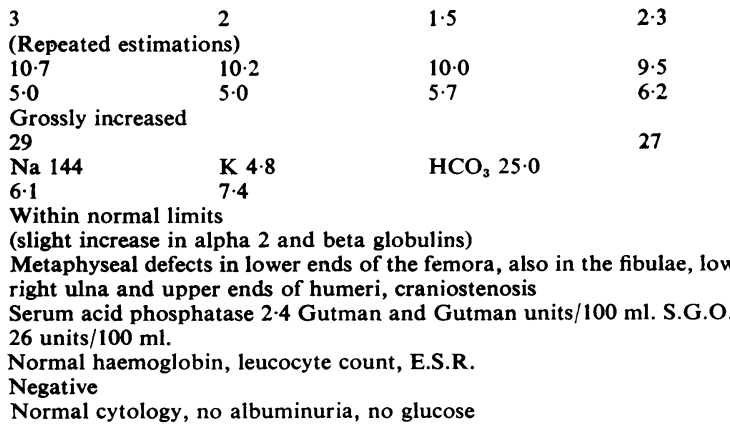

A right parietal cranioplasty was performed, this time with a full circumferential incision in the bone.

Convalescence was prolonged somewhat by wound infection, but after a course of chloromycetin she made a complete recovery, and has continued to develop well.

\section{FAMILY HISTORY}

Sixteen members of the family were seen, but in only 14 was the serum protein alkaline phosphatase distribution studied. There was no history of any bone disease, nor were the parents consanguineous. All four grandparents were well. There were four other children, aged 7 (boy), 6 (boy), 4 (girl), and 7 months (boy), all of whom were clinically well. The youngest boy, who had a very low serum alkaline phosphatase level, started to lose some teeth soon after they erupted, and was therefore considered to be affected by the disease, though radiographs of the skull and the right knee, taken at the age of 3 weeks, were normal. The eldest boy had a slight chest deformity, suggestive of residual Harrison's sulci. All the children had serum alkaline phosphatase values (15 to 25 King-Armstrong units $/ 100 \mathrm{ml}$,, Table III) well below the normal range for children.
Phosphoethanolamine eXCRetion Phosphoethanolo amine excretion was studied in 14 members of the family. In all of them urine extracts examined $\vec{b}$ chromatographically showed the presence of phos phoethanolamine. The estimations were not quantitative, and the extracts chromatographed represented larger volumes of urine than those used by Harris and Robson (1959). There appeared to be a gross increase in phosphoethanolamine excretion in thes propositus and her father, and the three brothers ano the paternal grandfather also seemed to excrete moros than the other members of the family. Phospho $\mathbb{D}$ ethanolamine was found in the urines of six out of seven controls, and thus under the test conditions the presence of this substance in the urine was of no? help in detecting heterozygotes for the hypo: phosphatasia gene(s).

LEUCOCYTE ALKALINE PHOSPHATASE This was estio mated histochemically by a slide method (Leonard Israëls, and Wilkinson, 1958). In all except two of the 14 relatives (a maternal aunt, $6 \%$ weakly positive, $94 \%$ negative, and a distant cousin, $2 \%$ strongly? positive, $15 \%$ weakly positive, $83 \%$ negative) ther reaction was either $100 \%$ negative or $1 \%$ weakly

TABLE II

BLOOD GROUPS
Subject

\begin{tabular}{ll}
\hline Propositus & Al B \\
Affected brother & B \\
Sister & Al B \\
Brother 1 & B \\
Brother 2 & B \\
Mother & B \\
Father & Al \\
Paternal grandmother & O \\
Paternal grandfather & Al \\
Maternal grandmother & B \\
Maternal grandfather & Al B \\
Maternal aunt & Al B \\
Maternal great-aunt (grandfather's sister) & Al B \\
Maternal great-aunt's daughter & B
\end{tabular}

$\begin{array}{lll}\text { MN } & \text { CC Dee } & \text { S negative } \\ \text { MN } & \text { Cc Dee } & \text { S negative } \\ \mathbf{N} & \text { Cc Dee } & \text { S positive } \\ \mathbf{N} & \text { Cc Dee } & \text { S positive } \\ \mathbf{N} & \text { Cc Dee } & \text { S positive } \\ \mathbf{N} & \text { Cc Dee } & \text { S negative } \\ \text { MN } & \text { CC Dee } & \text { S positive } \\ \text { MN } & \text { Cc Dee } & \text { S positive } \\ \text { MN } & \text { CC Dee } & \text { S negative } \\ \text { MN } & \text { Cc Dee } & \text { S negative } \\ \mathbf{N} & \text { Cc Dee } & \text { S negative } \\ \text { MN } & \text { Cc Dee } & \text { S negative } \\ \mathbf{N} & \text { Cc Dee } & \text { S positive } \\ \mathbf{N} & \text { cc ddee } & \text { S positive }\end{array}$




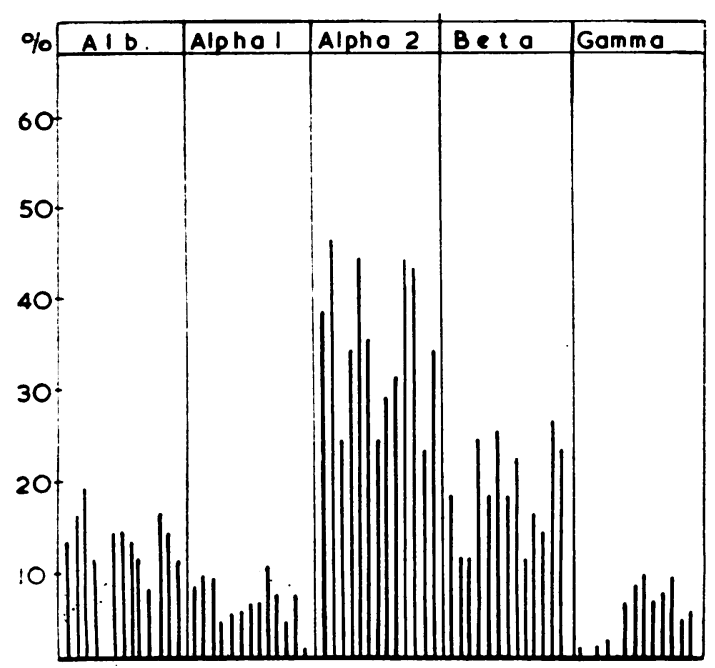

FIG. 2

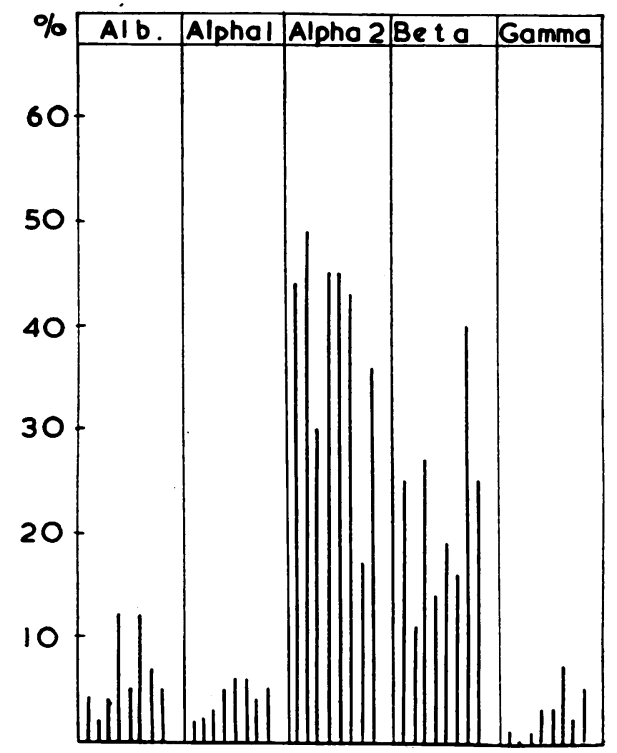

FIG. 3

FIGS. 2, 3, 4, and 5. Alkaline phosphatase distribution in the serum protein fractions, expressed as a percentage of the total serum alkaline phosphatase level.

Fig. 2, in normal adults; Fig. 3, in normal children; Fig. 4 , in affected siblings, in unaffected siblings, and in parents; Fig. 5, as in Fig. 4.

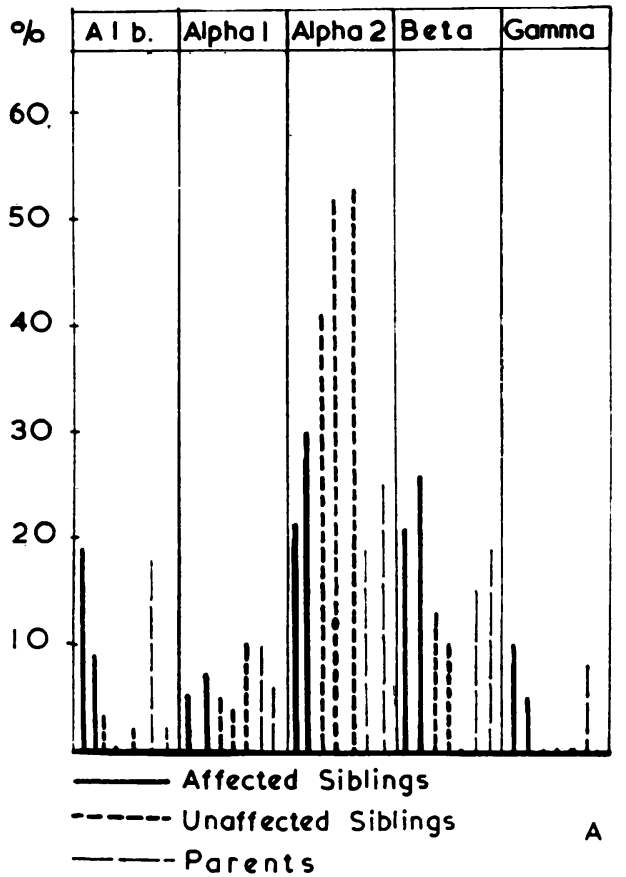

FIG. 4

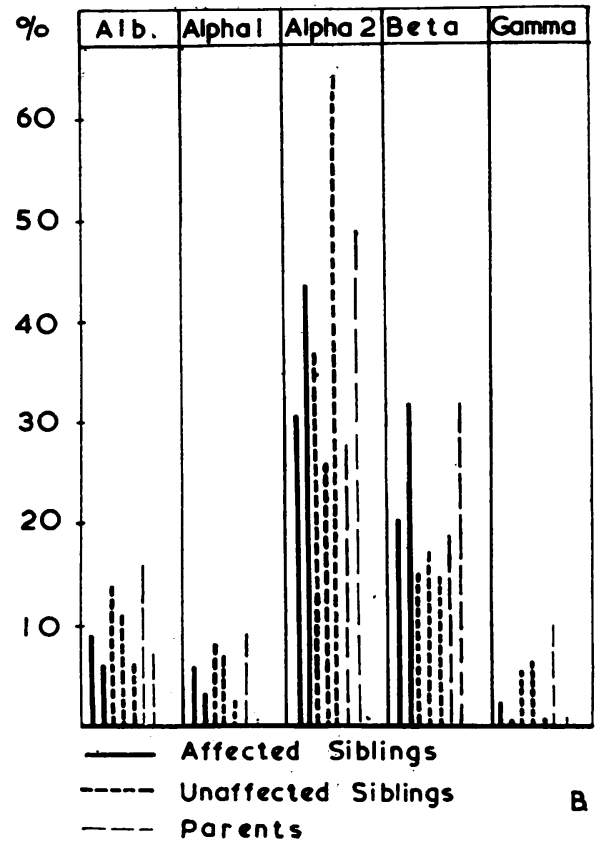

FIG. 5 


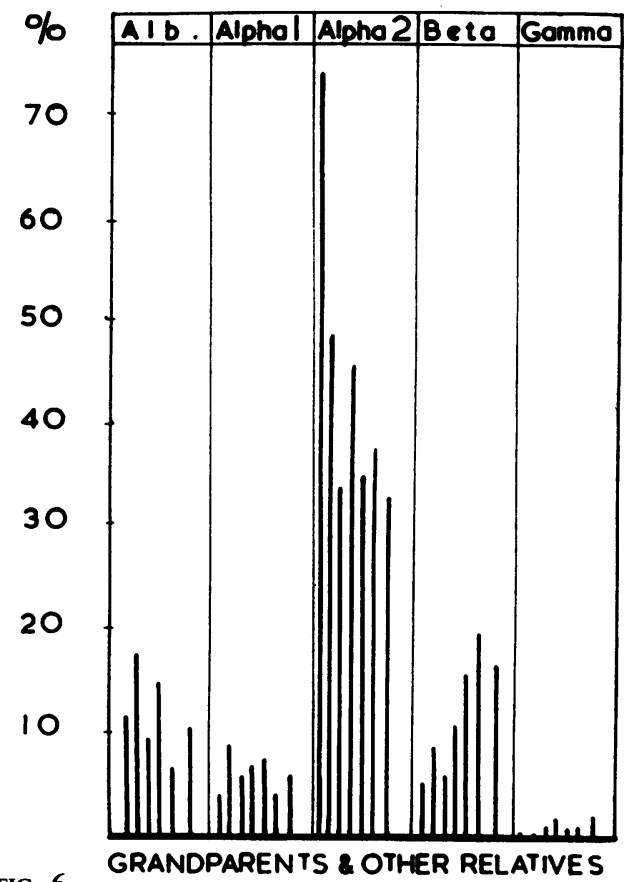

FIG. 6

FIG. 6. Alkaline phosphatase distribution in the serum protein fractions, expressed as a percentage of the total serum alkaline phosphatase level, in grandparents and other relatives. positive. In the propositus it was once $1 \%$ weakly $\frac{\stackrel{0}{\vec{\sigma}}}{\mathrm{\sigma}}$ positive but when measured three days after $\mathrm{a} \stackrel{.}{\Rightarrow}$ considerable leucocytosis $(36,000$ W.B.C./c.mm. $) \stackrel{\text { 品 }}{\circ}$ associated with a wound infection, the reaction was 0 $100 \%$ negative. Of two normal controls, one also had a $100 \%$ negative reaction and one had a $4 \% \frac{\bar{\omega}}{7}$ weakly positive reaction, $96 \%$ negative. A positive $\stackrel{\mathbb{\Phi}}{\propto}$ control had $80 \%$ strongly positive, $20 \%$ weakly positive leucocytes.

BLOOD GROUPS Genotyping was done by the Red $\overrightarrow{\vec{H}}$ Cross Blood Transfusion Service, Sydney (Table II). $\stackrel{\omega}{ }$ The results were recorded for possible use in future genetic studies.

ALKALINE PHOSPHATASE DISTRIBUTION IN SERUM PROTEIN FRACTIONS The alkaline phosphatase acti- $\bigcirc$ vity in the electrophoretically separated serum protein fractions was studied by a method described in a separate paper (Korner, 1962).

The normal pattern of distribution is shown in Figs. 2 and 3.

\section{THE FINDINGS IN HYPOPHOSPHATASIA}

THE PROPOSITUS AND HER AFFECTED BROTHER SER collected on two different occasions were studied. The results are set out in Table III and Figs. 4 and 5. In the propositus, levels in alpha 2 and beta globulins $\stackrel{\square}{\square}$ were equal in the first specimen, but in the second $\overrightarrow{\overrightarrow{0}}$

TABLE III

ALKaline PHOSPHATASE LEVELS EXPRESSED AS A PERCENTAGE OF THE TOTAL SERUM ALKALINE PHOSPHATASE

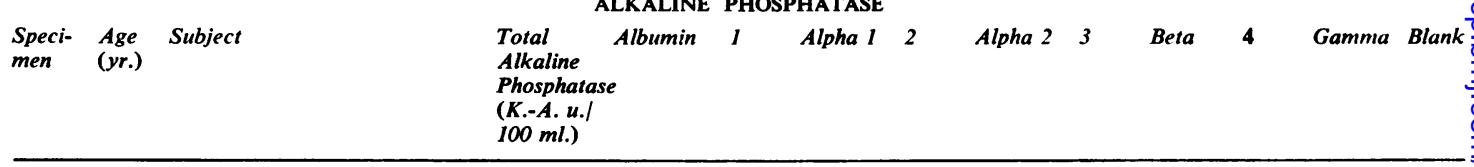

\begin{tabular}{|c|c|c|c|c|c|c|c|c|c|c|c|c|c|}
\hline \multicolumn{14}{|c|}{ Propositus and Affected Brother } \\
\hline 1 & 21 & Propositus & 3 & 19 & 1 & 5 & 7 & 21 & 7 & 21 & 8 & 10 & 5 \\
\hline 1 & $7 \mathrm{mt}$ & Affected brother & 2 & 9 & 3 & 7 & 2 & 30 & 8 & 26 & 7 & 5 & 4 \\
\hline 2 & 3 & Propositus & $2 \cdot 3$ & 9 & 5 & 6 & 5 & 31 & 16 & 20 & 7 & 3 & 2 \\
\hline 2 & $\begin{array}{l}1 \mathrm{yr} \text {. } \\
5 \mathrm{mt}\end{array}$ & Affected brother & 5 & 6 & $\mathbf{0}$ & 3 & 0 & 44 & 16 & 32 & $\mathbf{0}$ & 0 & 0 \\
\hline \multicolumn{14}{|c|}{ Parents and Clinically Normal Siblings } \\
\hline 1 & 7 & Brother A & 5 & 3 & 3 & 5 & 7 & 41 & 18 & 13 & 11 & $\mathbf{0}$ & 1 \\
\hline 1 & 6 & Brother B & 4 & $\mathbf{0}$ & 2 & 4 & 5 & 52 & 17 & 10 & 10 & 0 & $\mathbf{0}$ \\
\hline 1 & 4 & Sister & 5 & 2 & 2 & 10 & 2 & 53 & 30 & 0 & 0 & $\mathbf{0}$ & 2 \\
\hline 1 & 32 & Mother & 5 & 18 & 3 & 10 & 5 & 19 & 8 & 15 & 11 & 8 & 3 \\
\hline 1 & 32 & Father & 3 & 2 & 0 & 6 & 10 & 25 & 25 & 19 & 6 & $\mathbf{0}$ & 8 \\
\hline 2 & 8 & Brother A & 5 & 14 & 3 & 8 & 7 & 37 & 10 & 15 & 5 & 4 & 2 \\
\hline 2 & 7 & Brother B & 8 & 11 & 6 & 7 & 6 & 26 & 11 & 17 & 8 & 5 & 5 \\
\hline 2 & 5 & Sister & 5 & 6 & 0 & 2 & 2 & 64 & 11 & 15 & 1 & 0 & 1 \\
\hline 2 & 32 & Mother & 4 & 16 & 3 & 9 & 4 & 28 & 2 & 19 & 8 & 10 & 5 \\
\hline 2 & 32 & Father & $2 \cdot 5$ & 7 & $\mathbf{0}$ & 0 & 6 & 49 & 8 & 32 & 0 & $\mathbf{0}$ & $\mathbf{0}$ \\
\hline \multicolumn{14}{|c|}{ Other Relatives } \\
\hline 1 & 67 & Paternal grandfather & 7 & 1 & 1 & 4 & 1 & 75 & 12 & 5 & 0 & $\mathbf{0}$ & 2 \\
\hline $\mathbf{1}$ & 66 & Paternal grandmother & 4 & 12 & 2 & 9 & 7 & 49 & 11 & 9 & 2 & 0 & $\mathbf{1}$ \\
\hline 1 & 60 & Maternal grandfather & 3 & 18 & 6 & 6 & 3 & 34 & 10 & 16 & 4 & 1 & 3 \\
\hline 1 & 61 & Maternal grandmother & 5 & 10 & 1 & 7 & 5 & 46 & 13 & 11 & 4 & 2 & 1 \\
\hline 1 & 28 & Maternal aunt & 6 & 15 & 1 & 8 & 5 & 35 & 17 & 16 & 4 & 1 & 1 \\
\hline$i$ & 59 & Maternal great-aunt & 6 & 7 & 2 & 4 & 4 & 38 & 19 & 20 & 6 & 1 & i \\
\hline$i$ & 17 & Maternal great-aunt's daughter & 6 & 11 & 4 & 6 & 3 & 33 & 12 & 17 & 11 & 2 & 2 \\
\hline
\end{tabular}


specimen there was the usual peak in alpha 2 . Albumin had a relatively high proportion of total activity in specimen $1(19 \%)$ and less in specimen 2 $(9 \%)$.

The affected brother had the usual peak in alpha 2 in both sera, with slightly less activity in the beta band.

PARENTS AND THREE OTHER SIBLINGS The results on the two sets of sera are set out in Table III and Figs. 4 and 5. The pattern of distribution of enzyme activity was normal.

REMAINDER OF THE FAMILY Four grandparents, a maternal aunt, and a maternal great-aunt and her daughter were available for study (Table III and Fig. 6). The pattern of alkaline phosphatase distribution was normal in all.

\section{DISCUSSION}

The distribution of alkaline phosphatase activity in the serum protein fractions in patients with hypophosphatasia and their relatives appears to be normal, with the usual peak in alpha 2 globulins, somewhat lower beta activity, and low activity in the albumin and the alpha 1 and gamma globulins. The serum alkaline phosphatases in this condition thus resemble normal alkaline phosphatases in electrophoretic mobility, and this is in keeping with the concept of hypophosphatasia as a quantitative enzyme deficiency affecting all the tissues which normally contain alkaline phosphatase.

Most of the physiological processes associated with the action of alkaline phosphatase do not seem to be detectably deranged in hypophosphatasia, e.g., the renal re-absorption of glucose, and defective mineralization of bone and the loss of primary teeth are the only abnormalities directly attributable to the enzyme deficiency.

It is of interest that all five siblings had low serum alkaline phosphatase levels confirmed by repeated estimations. The most likely explanation is that the three clinically normal children were heterozygous carriers of a recessive gene and consequently displayed some biochemical abnormality. On the data available the possibility of inheritance by means of a dominant gene with variable expressivity could not be excluded.

The presence of phosphoethanolamine in the urine, measured under our test conditions, was of no help in detecting heterozygotes, as this substance was also found in normal urines.

This work was supported by a grant from the Medical Research Committee, St. Vincent's Hospital, Sydney.

My thanks are due to Miss L. Silvester for performing the estimations of phosphoethanolamine excretion, and to Dr. R. D. Rothfield for help and advice. I also wish to thank Dr. W. J. Burke, Sir Douglas Miller, and Mr. J. L. Dowling for permission to publish details of the case.

\section{REFERENCES}

Beisel, W. R., Austen, K. F., Rosen, H., and Herndon, E. G. (1960). Amer. J. Med., 29, 369.

- Benjamin, N., and Austen, K. F. (1959). Blood, 14, 975.

Engfeldt, B., and Zetterström, R. (1954). J. Pediat., 45, 125.

Fraser, D. (1957). Amer. J. Med., 22, 730.

Harris, H., and Robson, E. B. (1959). Ann. hum. Genet., 23, 421.

Keiding, N. R. (1959). Scand. J. clin. Lab. Invest., 11, 106.

Korner, N. H. (1962). J. clin. Path., 15, 195.

Leonard, B. J., Israëls, M. C. G., and Wilkinson, J. F. (1958). Lancet, $1,289$.

McCance, R. A., Fairweather, D. V. I., Barrett, A. M., and Morrison, A. B. (1956). Quart. J. Med., 25, 523.

Rosenberg, I. N. (1959). J. clin. Invest., 38, 630.

Sobel, E. H., Clark, L. C., Fox, R. P., and Robinow, M. (1953). Pediatrics, 11, 309. 